\title{
RADIOCARBON MARINE RESERVOIR AGES IN THE NORTHWESTERN PACIFIC OFF HOKKAIDO ISLAND, JAPAN, DURING THE LAST DEGLACIAL PERIOD
}

\author{
Ken'ichi Ohkushi ${ }^{1} \bullet$ Masao Uchida $^{2} \bullet$ Kaori Aoki $^{3} \bullet$ Minoru Yoneda $^{4} \bullet$ Ken Ikehara $^{5} \bullet$ \\ Kayo Minoshima $^{5} \bullet$ Hodaka Kawahata $^{4} \bullet$ Ryuji Tada $^{4} \bullet$ Masafumi Murayama $^{6} \bullet$ Yasuyuki Shibata $^{7}$
}

\begin{abstract}
We measured radiocarbon ages of planktic foraminifera in 4 sediment cores from the northwestern Pacific region off northern Japan in order to estimate marine reservoir ages during the Bølling-Allerød period. The ages of deglacial tephra markers from 2 Japanese source volcanoes identified in these sediment cores had been previously estimated from ${ }^{14} \mathrm{C}$ ages of terrestrial charcoal and buried forests. By comparing the foraminiferal and tephra ages, we estimated the surface water reservoir age during the Bølling-Allerød period to be $\sim 1000 \mathrm{yr}$ or more in the region off northern Japan. The deglacial reservoir ages were more than $200 \mathrm{yr}$ higher than the Holocene values of $\sim 800 \mathrm{yr}$. The older deglacial ages may have been caused by active upwelling of deep water during the last deglaciation and the consequent mixing of "older" deep water with "younger" surface waters.
\end{abstract}

\section{INTRODUCTION}

Radiocarbon dates obtained from material of marine origin are widely used for dating oceanic paleoenvironmental events and as tracers of ocean circulation (Southon et al. 1990; Sikes et al. 2000). However, little is known about past changes in regional marine reservoir ages in the northwestern Pacific. We studied ${ }^{14} \mathrm{C}$ marine reservoir ages in the region off northern Japan during the last deglacial period. Our approach to determine past reservoir ages was based on tephras, dated with terrestrial ${ }^{14} \mathrm{C}$ and used as stratigraphic marker beds, which allowed surface water ${ }^{14} \mathrm{C}$ ages to be related directly to the atmosphere. Many widespread Quaternary tephras have been identified in Japan. To estimate the marine reservoir ages, we compared ${ }^{14} \mathrm{C}$ ages of planktic foraminifera with the ${ }^{14} \mathrm{C}$ ages of 2 tephras (Towada-Hachinohe and Nigorikawa tephras) from Japanese volcanoes (Figure 1). The Towada-Hachinohe (To-H) tephra was erupted from Towada Volcano, which is near the northern end of Honshu Island (Figure 1). Two ${ }^{14} \mathrm{C}$ ages of forests buried in the To- $\mathrm{H}$ tephra dated to $12,660 \pm 150 \mathrm{BP}$ and $12,640 \pm 150 \mathrm{BP}$ (Terada et al. 1994). The ${ }^{14} \mathrm{C}$ ages were calibrated with the CALIB v 5.0 program (Stuiver et al. 2005), using the IntCal04 data set (Reimer et al. 2004). The calendar age was estimated to be $14,580-15,160 \mathrm{cal}$ BP $(1 \sigma)$.

The Nigorikawa ( $\mathrm{Ng}$ ) tephra was erupted from the Nigorikawa caldera, on the shore of Funka Bay, southwestern Hokkaido Island (Figure 1). The tephra is distributed around the caldera and over a wide area in southwestern Hokkaido. The ${ }^{14} \mathrm{C}$ ages of charcoal and wood fragments buried in the Nigorikawa tephra are 12,020 $\pm 190 \mathrm{BP}$ and 12,270 $\pm 190 \mathrm{BP}$, respectively (Yanai et al. 1992). The calendar age was estimated to be 13,760-14,320 cal BP $(1 \sigma)$. A study of pollens in terrestrial sediments intercalated by the $\mathrm{Ng}$ tephra documented the occurrence of the Bølling-Allerød warming event just after the accumulation of the $\mathrm{Ng}$ tephra (Takiya and Hagiwara 1997).

\footnotetext{
'Faculty of Human Development, Kobe University, 3-11 Tsurukabuto, Nada-ku, Kobe 657-8501, Japan. Corresponding author. Email: ohkushi@penguin.kobe-u.ac.jp.

${ }^{2}$ Japan Agency for Marine-Earth Science and Technology (JAMSTEC), Yokosuka 237-0061, Japan.

${ }^{3}$ University of Toronto, Toronto, Ontario M5S 3B 1, Canada.

${ }^{4}$ Graduate School of Frontier Sciences, University of Tokyo, Nakano-ku 164-8639, Japan.

${ }^{5}$ Institute of Geology and Geoinformation, National Institute of Advanced Industrial Science and Technology (AIST), 1-1-1 Higashi, Tsukuba, 305-8567, Japan.

${ }^{6}$ Kochi University, Kochi 783-8502, Japan.

${ }^{7}$ National Institute for Environmental Studies, Tsukuba 305-0051, Japan.
} 


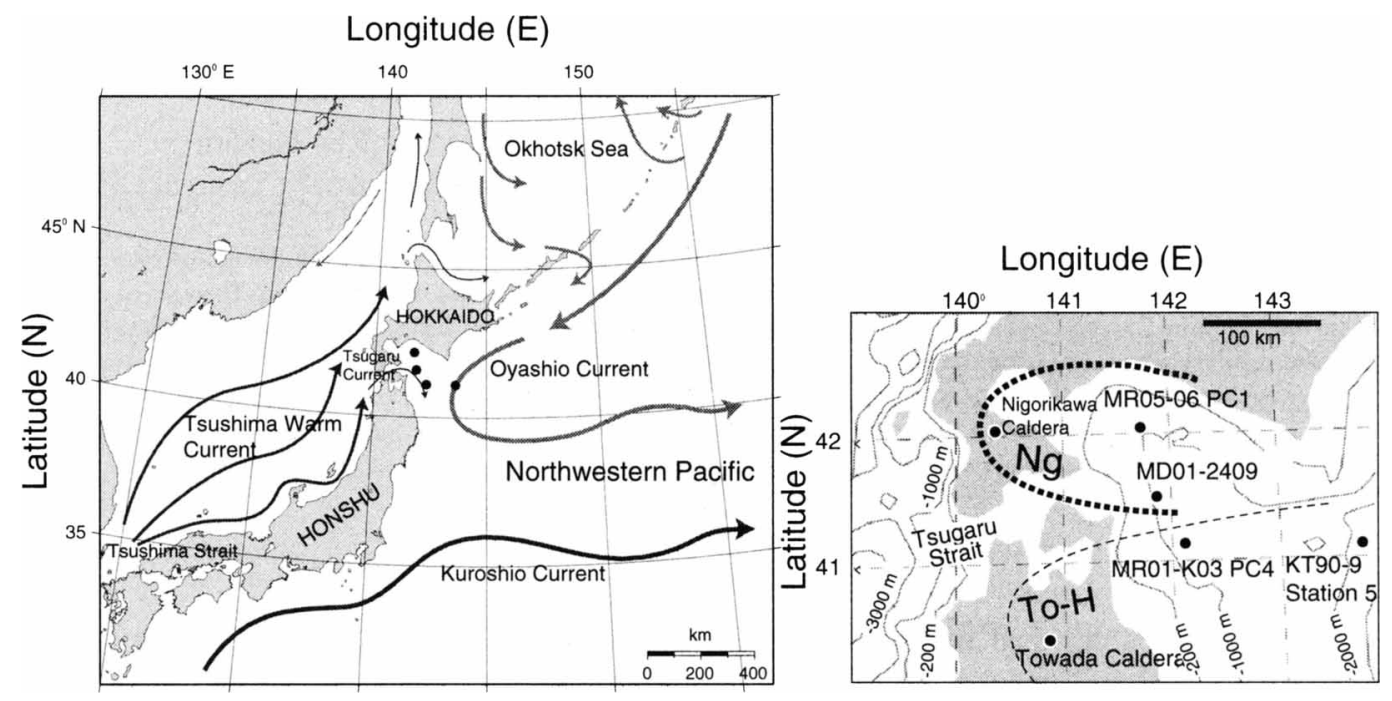

Figure 1 Location map of cores MD01-2409, KT90-9 Station 5, MR01-K03 PC4, MR04-06 PC1, and the study area. The thick dotted line in the right-hand panel shows the distribution of the Nigorikawa tephra, compiled by Yanai et al. (1992). The thin dashed line indicates the distribution of the Towada-Hachinohe tephra, compiled by Hayakawa (1983). $\mathrm{Ng}=\mathrm{Nigorikawa}$ tephra; To-H = Towada-Hachinohe tephra.

\section{SAMPLES AND METHODS}

Four piston core sediment samples used for this study were collected from the northwestern Pacific region off Shimokita Peninsula (Honshu Island) and eastern Hokkaido Island, northern Japan (Figure 1). Core MD01-2409 $\left(41^{\circ} 33^{\prime} \mathrm{N}, 141^{\circ} 52^{\prime} \mathrm{E}\right)$ was taken from a water depth of $975 \mathrm{~m}$ near the eastern entrance of the Tsugaru Strait, which joins the northwestern Pacific with the Sea of Japan, during the IMAGES VII - WEPAMA (West Pacific Margin) cruise of the research vessel (R/V) Marion Dufresne. This core consists mainly of massive mud. Two well-preserved laminated sediment horizons occur in the middle of this core. According to the age model of Kuroyanagi et al. (2006), the upper laminated layer (core depth 694-860 cm) ranges in age from 11,275 to $10,352 \mathrm{cal}$ BP. The lower laminated layer (969-1131 cm depth) ranges from 15,608 to $12,960 \mathrm{cal} \mathrm{BP}$ and is intercalated by the $\mathrm{Ng}$ tephra (1099-1100 cm depth) (Aoki and Ohkushi 2006). Core MR01-K03 PC4 $\left(41^{\circ} 07^{\prime} \mathrm{N}, 142^{\circ} 24^{\prime} \mathrm{E}\right)$ was collected from a water depth of $1363 \mathrm{~m}$ off Shimokita Peninsula during the MR01-K03 cruise of the R/V Mirai. This core consists of massive mud intercalated by the To-H tephra (419-423 cm depth). Core KT90-9 Station $5\left(41^{\circ} 06^{\prime} \mathrm{N}, 143^{\circ} 30^{\prime} \mathrm{E}\right)$ was collected from a water depth of 2048 m south of Cape Erimo, Hokkaido, during the KT 90-9 cruise of the R/ $\mathrm{V}$ Tansei-Maru. This core consists of massive mud intercalated by the To-H tephra (300-308 cm depth). Another core, MR04-06 PC1 $\left(42^{\circ} 09^{\prime} \mathrm{N}, 141^{\circ} 42^{\prime} \mathrm{E}\right)$, was taken from a water depth of $788 \mathrm{~m}$ off Tomakomai, southeastern Hokkaido, during the MR04-06 cruise of the R/V Mirai. This core consists of massive mud intercalated by the $\mathrm{Ng}$ tephra $(1242-1265 \mathrm{~cm}$ depth).

For accelerator mass spectrometry (AMS) ${ }^{14} \mathrm{C}$ analysis, specimens of the planktic foraminifer Neogloboquadrina pachyderma were picked from sediment samples around tephra layers. These specimens were cleaned ultrasonically in $\mathrm{H}_{2} \mathrm{O}_{2}(30 \%)$ and subsequently dissolved in $100 \%$ phosphoric acid within evacuated glass vessels at $25^{\circ} \mathrm{C}$. The graphitization of samples was carried out according to the procedure described by Uchida et al. (2004). The ${ }^{14} \mathrm{C}$ analyses were conducted at the AMS facility at the National Institute for Environmental Studies (NIES-TERRA, Tsukuba, Japan) (Tanaka et al. 2000). The results are listed in Table 1. 


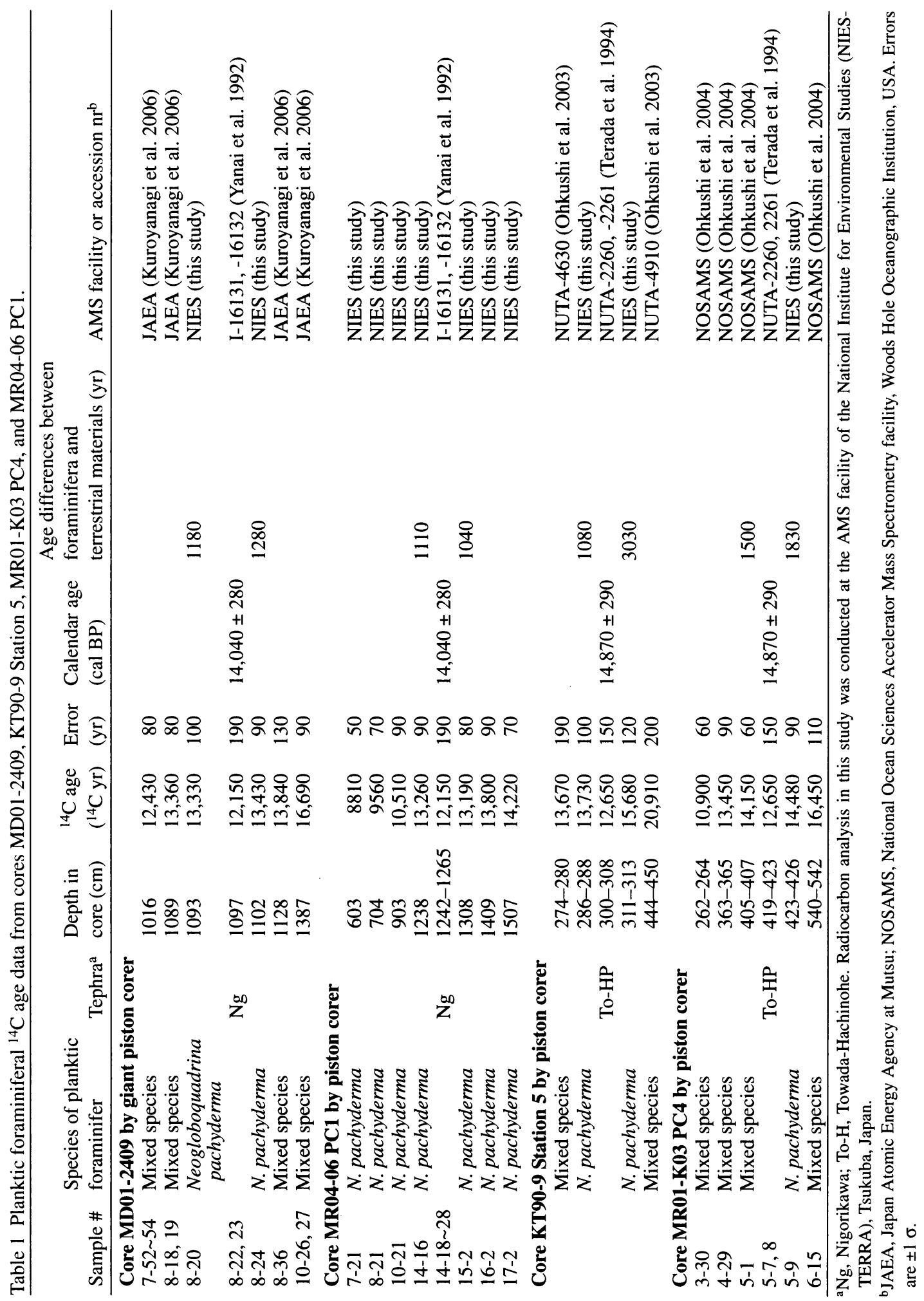




\section{RESULTS AND DISCUSSION}

Planktic foraminiferal ${ }^{14} \mathrm{C}$ ages are listed in Table 1 and are shown in Figure 2. In core MD01-2409, the ${ }^{14} \mathrm{C}$ age difference between the foraminifera and the $\mathrm{Ng}$ tephra was $1180 \mathrm{yr}$ at $4 \mathrm{~cm}$ above the $\mathrm{Ng}$ tephra, and $1280 \mathrm{yr}$ at $5 \mathrm{~cm}$ below the tephra. In core MR04-06 PC1, the ${ }^{14} \mathrm{C}$ age difference with the $\mathrm{Ng}$ tephra was $1110 \mathrm{yr}$ at $4 \mathrm{~cm}$ above the tephra and $1040 \mathrm{yr}$ at $43 \mathrm{~cm}$ below the tephra. Thus, we estimated the difference between the foraminiferal and the $\mathrm{Ng}$ tephra ages to be $1040 \mathrm{yr}$ or more. In core KT90-9 Station 5, the age difference between the foraminifera and the To- $\mathrm{H}$ tephra was $1080 \mathrm{yr}$ at $12 \mathrm{~cm}$ above the To-H tephra and $3030 \mathrm{yr}$ at $3 \mathrm{~cm}$ below the tephra. In core MR01-K03 PC4, the age difference between the foraminifera and the To- $\mathrm{H}$ tephra was $1500 \mathrm{yr}$ at $12 \mathrm{~cm}$ above To- $\mathrm{H}$ and $1830 \mathrm{yr}$ just below To-H. Thus, we estimated the age difference between the foraminifera and the To-H tephra to be 1080 yr or more.

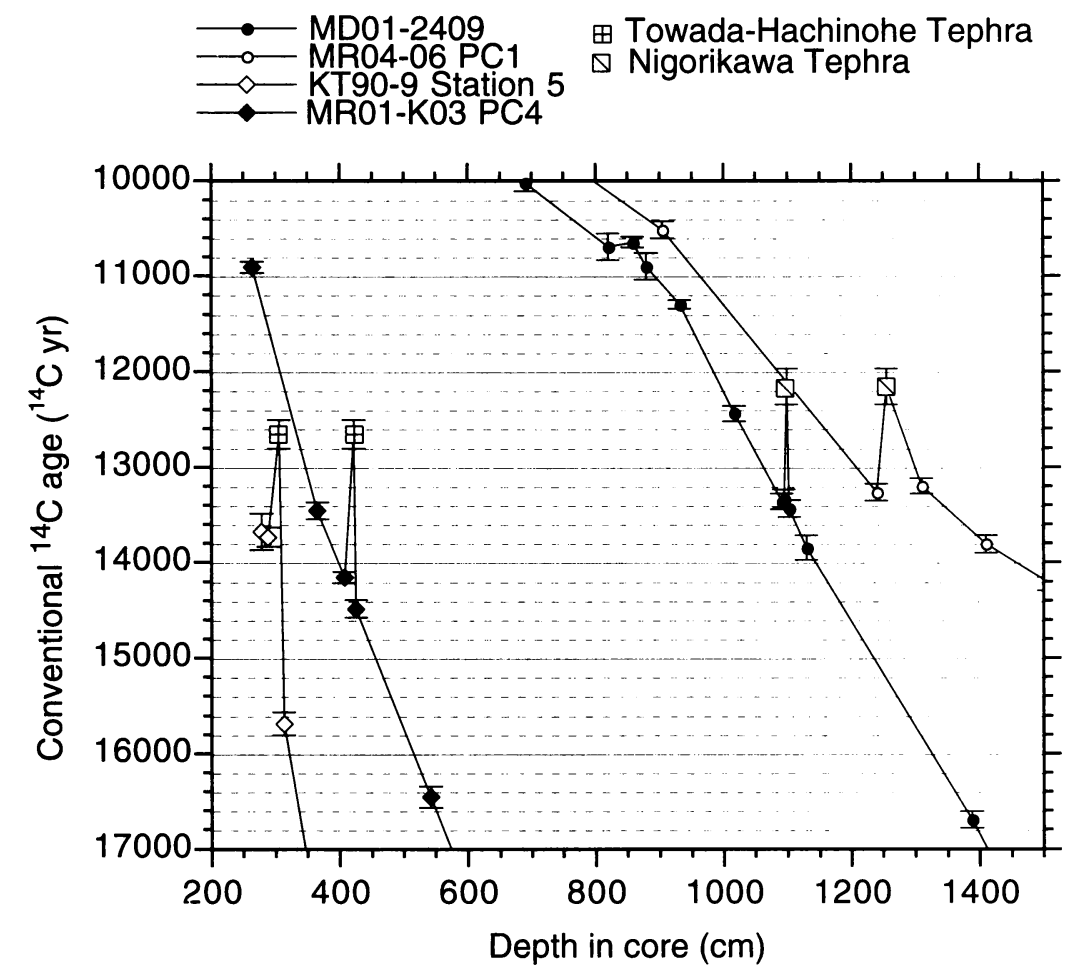

Figure 2 Depth- ${ }^{14} \mathrm{C}$ age plots of planktic foraminifera and tephra layers

In this way, we estimated reservoir ages in the northwestern Pacific during the Bølling-Allerød period to be $1000 \mathrm{yr}$ or more, based on the ${ }^{14} \mathrm{C}$ age differences between the ages of the 2 tephras and those of the foraminifera. On the other hand, ${ }^{14} \mathrm{C}$ data from archaeological deposits suggest that in the middle Holocene, the reservoir age was about $800 \mathrm{yr}$ around Hokkaido Island (Yoneda et al. 2001). Similarly, ${ }^{14} \mathrm{C}$ data from mollusk shells from pre-bomb shell middens yield a reservoir age of $710 \mathrm{yr}$ for the northwestern Pacific near the southern Kurile Islands (Kuzmin et al. 2001). Our results indicate that the deglacial reservoir ages were more than $200 \mathrm{yr}$ higher than Holocene reservoir ages. These results suggest active upwelling of deep water during the last deglaciation, leading to mixing of older deep water with younger surface waters. 
The northwestern Pacific off northern Japan is the site of confluence of the cold Oyashio Current and the warm Kuroshio Current, with additional influence from the warm Tsugaru Current, which flows from the marginal Sea of Japan through the shallow Tsugaru Strait (sill depth $\sim 130 \mathrm{~m}$ ). These oceanographic features drastically changed from the last glacial to the Holocene. Glacio-eustatic sea-level lowering isolated the Sea of Japan, resulting in restricted outflow of the warm Tsugaru Current (Oba et al. 1991; Takei et al. 2002). When the sea level rose during the deglaciation, a branch of the Oyashio Current began to flow into the Sea of Japan via the Tsugaru Strait (Oba et al. 1991; Takei et al. 2002). Thus, the large reservoir ages in this study indicate the deglacial values of the Oyashio Current, reflecting strong depletion of ${ }^{14} \mathrm{C}$ in the subarctic North Pacific. Moreover, benthic-planktic foraminiferal ${ }^{14} \mathrm{C}$ age differences in the $\mathrm{PC} 4$ core indicate that ventilation ages during the Bølling-Allerød period were 500-1000 yr larger than modern seawater ${ }^{14} \mathrm{C}$ ventilation ages at mid-depths (Ahagon et al. 2003). On the other hand, the benthic-planktic ${ }^{14} \mathrm{C}$ age differences indicate during the $\mathrm{H} 1$ cold event, 500-1000 yr smaller ventilation ages than during the BøllingAllerød period, reflecting active production of the North Pacific Intermediate Water in the subarctic Pacific (Ohkushi et al. 2003, 2004). At the onset of the Bølling-Allerød period, active upwelling of deep water probably started because of restricted intermediate water production. In addition, the active upwelling of deep water in the North Pacific may be related to the formation of the North Atlantic Deep Water during the Bølling-Allerød period.

\section{CONCLUSION}

We obtained ${ }^{14} \mathrm{C}$ marine reservoir ages for the region off northern Japan during the last deglacial period. The surface water reservoir ages during the Bølling-Allerød period were estimated to be $1000 \mathrm{yr}$ or more. The deglacial reservoir ages were more than $200 \mathrm{yr}$ higher than the Holocene values of about $800 \mathrm{yr}$. The results suggest active upwelling of deep water during the last deglaciation and the mixture of older deep water with younger surface waters.

\section{ACKNOWLEDGMENTS}

We greatly thank N Ahagon, K Kimoto, M Suzuki, A Shibahara, M Hoshiba, I Motoyama, A Nishimura, M Shirai, H Narita, and T Oba for sample preparation; the captain, crew, and Marine Work Japan and scientific staff of the MR01-K03 and MR04-06 cruises of the R/V Mirai for their kind cooperation at sea; and 2 anonymous reviewers for their kind support. This research is part of the "Study on Past Marine Environmental Changes" program, sponsored by the Japan Agency for Marine-Earth Science and Technology.

\section{REFERENCES}

Ahagon N, Ohkushi K, Uchida M, Mishima T. 2003. Mid-depth circulation in the northwest Pacific during the last deglaciation: evidence from foraminiferal radiocarbon ages. Geophysical Research Letters 30(21): 2097; doi:10.1029/2003GL018287.

Aoki K, Ohkushi K. 2006. Nigorikawa tephra recognized in the sediment core MD01-2409 collected off the Shimokita Peninsula. Quaternary Research [Japanese] 45(3):257-60. In Japanese.

Hayakawa Y. 1983. The Hachinohe ash: an example of an accretionary lapilli-fall deposit from Towada Volcano, Japan. Bulletin of the Volcanological Society of Japan 28:25-40. In Japanese with English abstract.

Kuroyanagi A. Kawahata H, Narita H, Ohkushi K, Ara- maki T. 2006. Reconstruction of paleoenvironmental changes based on the planktonic foraminiferal assemblages off Shimokita (Japan) in the northwestern North Pacific. Global and Planetary Change 53(1-2): 92-107.

Kuzmin YV, Burr GS, Jull AJT. 2001. Radiocarbon reservoir correction ages in the Peter the Great Gulf, Sea of Japan, and eastern coast of the Kunashir, southern Kuriles (northwestern Pacific). Radiocarbon 43(2A): 477-81.

Oba T, Murayama M. 2004. Sea-surface temperature and salinity changes in the northwest Pacific since the Last Glacial Maximum. Journal of Quaternary Science 19(4):335-46. 
Oba T, Kato M, Kitazato H, Koizumi I, Omura A, Sakai T, Takayama T. 1991. Paleoenvironmental changes in the Japan Sea during the last 85,000 years. Paleoceanography 6(4):499-518.

Ohkushi K, Itaki T, Nemoto N. 2003. Last GlacialHolocene change in intermediate-water ventilation in the northwestern Pacific. Quaternary Science Reviews 22(14):1477-84.

Ohkushi K, Uchida M, Ahagon N, Mishima T, Kanamatsu T. 2004. Glacial intermediate water ventilation in the northwestern Pacific based on AMS radiocarbon dating. Nuclear Instruments and Methods in Physics Research B 223-224:460-5.

Reimer PJ, Baillie MGL, Bard E, Bayliss A, Beck JW, Bertrand CJH, Blackwell PG, Buck CE, Burr GS, Cutler KB, Damon PE, Edwards RL, Fairbanks RG, Friedrich M, Guilderson TP, Hogg AG, Hughen KA, Kromer B, McCormac G, Manning S, Bronk Ramsey C, Reimer RW, Remmele S, Southon JR, Stuiver M, Talamo S, Taylor FW, van der Plicht J, Weyhenmeyer CE. 2004. IntCal04 terrestrial radiocarbon age calibration, 0-26 cal kyr BP. Radiocarbon 46(3): 1029-58.

Sikes EL, Samson CR, Guilderson TP, Howard WR. 2000. Old radiocarbon ages in the southwest Pacific Ocean during the last glacial period and deglaciation. Nature 405(6786):555-9.

Southon JR, Nelson DE, Vogel JS. 1990. A record of past ocean-atmosphere radiocarbon differences from the northeast Pacific. Paleoceanography 5(2): 197-206.

Stuiver M, Reimer PJ, Reimer RW. 2005. CALIB 5.0. [WWW program and documentation]. Seattle: Quaternary Research Center, University of Washington. http://radiocarbon.pa.qub.ac.uk/calib/calib.html.

Takei T, Minoura K, Tsukawaki S, Nakamura T. 2002. Intrusion of a branch of the Oyashio Current in to the Japan Sea during the Holocene. Paleoceanography 17(3):1039; doi:10.1029/2001PA000666.

Takiya M, Hagiwara N. 1997. Vegetation history of Mt. Yokotsudake, southwestern Hokkaido, since the last glacial. Quaternary Research [Japanese] 35:217-34. In Japanese with English abstract.

Tanaka A, Yoneda M, Uchida M, Uehiro T, Shibata Y, Morita M. 2000. Recent advances in ${ }^{14} \mathrm{C}$ measurement at NIES-TERRA. Nuclear Instruments and Methods in Physics Research B 172(1-4):107-11.

Terada K, Ohta S, Suzuki M, Noshiro S, Tsuji S. 1994. Dendrochronology of forests buried in Hachinohe tephra on the eastern slope of Towada Volcano, northern Japan. Quaternary Research [Japanese] 33:153-64. In Japanese with English abstract.

Uchida M, Shibata Y, Yoneda M, Kobayashi T, Morita M. 2004. Technical progress in AMS microscale radiocarbon analysis. Nuclear Instruments and Methods in Physics Research B 223-224:313-7.

Yanai S, Ganzawa Y, Komori Y. 1992. The stratigraphy and distribution of the Nigorikawa tephra, latest glacial age time-marker in southwest Hokkaido. Journal of the Geological Society of Japan 98:125-36. In Japanese with English abstract.

Yoneda M, Hirota M, Uchida M, Uzawa K, Tanaka A, Shibata Y, Morita M. 2001. Marine radiocarbon reservoir effect in the western North Pacific observed in archaeological fauna. Radiocarbon 43(2A):465-71. 